Issledovatel'skiy Zhurnal Russkogo Yazyka i Literatury, Vol. 9, Issue 2, 2021, Pp: 27-51

DOI: 10.52547/iarll.18.27 DOR: 20.1001.1.23452498.2021.9.2.2.0

Article No.: 18.21.20212.2751

Scientific Article

\title{
Iranian Poets and Poetry in the Vision of Russian Poets \\ (Linguoimagological Aspect)
}

\author{
Ivanova Lyudmila Petrovna ${ }^{1 *}$ \\ Professor of National Pedagogical Dragomanov University, \\ Kiev, Ukraine.
}

(date of receiving: May, 2021; date of acceptance: July, 2021)

\begin{abstract}
In the article on the material of works of Russian poets who wrote about Iran / Persia ("Persian motives" by SA Esenin, "Death of Vazir-Mukhtar" by YN Tynyanov, the fundamental work of Iranian colleagues Marzieh Yahyapour and Janollah KarimiMotahhar "Saadi and Russian poets"), the image of this country is recreated, which is the goal of linguoimagological research. On the one hand, there is a deep immersion in the classical poetry of medieval Persia (the work and personalities of Saadi, Ferdowsi, Omar Khayyam, Hafez), on the other hand, masterpieces of Russian poetry have been created over the course of two centuries (from A.S. Pushkin to S.A.). In our country, classical Persian poetry has been known since the 19th century. Getting to know her and Persia, Russian poets showed themselves as educated, erudite, benevolent and sensitive to creativity. None of them have been to Persia, but the image of the country through the prism of poetry has formed a multifaceted, interesting and mysterious.
\end{abstract}

Keywords: Linguoimagology, Persian Poets and Poetry, Saadi, Ferdowsi, Omar Khayyam, Hafez.

1. E-mail: lupiv1303@gmail.com *Corresponding author 


\title{
Иранские поэты и поэзия в видении русских поэтов (лингвоимагологический аспект)
}

\author{
Иванова Людмила Петровна ${ }^{1 *}$
}

Профессор, Национальный педагогический университет им.

\author{
М. П. Драгоманова, \\ Киев, Украина.
}

(дата получения: май 2021 г.; дата принятия: июль 2021 г.)

\begin{abstract}
Аннотация
В статье на материале произведений русских поэтов, писавших об Иране/Персии («Персидские мотивы» С. А. Есенина, «Смерть Вазир-Мухтара» Ю.Н. Тынянова, фундаментальный труд иранских коллег Марзие Яхьяпур и Джанолаха Карими-Мотаххара «Саади и русские поэты»), воссоздается образ этой страны, что является целью лингвоимагологического исследования. С одной стороны, наблюдается глубокое погружение в классическую поэзию средневековой Персии (творчество и личности Саади, Фирдоуси, Омара Хайяма, Хафиза), с другой стороны, на протяжении двух столетий создаются шедевры русской поэзии (от А. С Пушкина до С. А. Есенина). В нашей стране классическая персидская поэзия была известна с XIX века. Познавая ее и Персию, русские поэты проявились как образованные, эрудированные, благожелательные и тонко чувствующие творчество. Никто из них в Персии не бывал, однако образ страны скозь призму поэзии сформировался многогранный, интересный и загадочный.
\end{abstract}

Ключевые слова: Лингвоимагология, Персидские Поэты И Поэзия, Саади, Фирдоуси, Омар Хайям, Хафиз.

1. E-mail: lupiv1303@gmail.com * Ответственный автор 


\section{Введение}

Далекий загадочный Иран, а ранее Персия, на протяжении многих лет привлекали внимание русских литераторов. Их произведения об этой стране и стали основой нашего исследования, выполненного в рамках лингвоимагологии - проанализируем образ Персии в русском языковом сознании XIX-XX веков. Материалом послужили «Персидские мотивы» С. А. Есенина, «Смерть Вазир-Мухтара» Ю. Н. Тынянова, а главное фундаментальный труд иранских коллег Марзие Яхьяпур и Джанолаха Карими-Мотаххара «Саади и русские поэты», внесший весомый вклад в развитие нашей науки. В ходе подготовки к анализу нас поразил следующий момент: практически никто, на чьи произведения ссылаемся, сам не был в Иране, образ этой страны складывался на базе впечатлений, полученных из самых различных источников, прежде всего - произведений классиков персидской литературы. Нам же выпала честь участвовать в конференции по русистике, проведенной в Тегеранском университете, поэтому возьмем на себя смелость в некоторых случаях приводить собственные впечатления.

\section{Основная часть}

\section{Персидские поэты и поэзия}

Учитывая материал для анализа, начнем с персидской поэзии. В «Краткой литературной энциклопедии» И. С. Брагинский отмечает: «Персидская литература - одна из древнейших литератур мира, получившая начало в памятниках древнеиранской письменности 1-го тысячелетия до н.э. Поскольку в 9-15 в.в. персидский язык (фарси дари) был литературным языком не только иранских народов (персов, таджиков, афганцев, курдов), но и многих тюркоязычных народов (азербайджанцев, турок, узбеков, туркмен), а также 
мусульман Индии, то к персидской литературе обычно относятся сочинения многих авторов этих народов до 15 в. (Брагинский 1968. 678-679).

Рассматриваемые поэты - представители классической персидской литературы. Произведения их были известны в России. Так, А. С. Пушкин писал:

«Благословен твой подвиг новый,

Твой путь на север наш суровый,

Где кратко изарствует весна,

Но где Гафиза и Саади

Знакомьк... имена)»

(«Фазель-Хану») (Яхьяпур, Карими-Мотаххар 2017. 135) ${ }^{1}$

Обратим внимание на противительный союз 'но'. В сознании русского поэта представители южного края воспринимаются как необычные, противопоставления севера и юга распространяется и на поэзию.

С другой стороны, писатель XX века Ю. Н. Тынянов, посвятивший роман современнику и близкому знакомому А. С. Пушкина, А. С. Грибоедову, в 8-й главе описывает экзамен по переводу с персидского языка, в котором главную роль взял на себя Сеньковский, Грибоедов был в составе комиссии:

«Вдруг Грибоедов протянул вперед руку.

- Прочтите, - сказал он, ульюбаясь, - из «Гюлистана» рассказ

двадйать

семь, конеи.

Сеньковский остановился с открытым ртом.

- «Или нет более честности в мире, - читал ученик, - или, быть

1. В дальнейшем стихи в тексте статьи, цитируемых по книке «Саади и русские поэты», в скобках указываются страницы. 
может, никто в наше время не исполняет ее условий. Никто не выучился у меня метанию стрел, чтобы под конеи не обратить меня в мимень».

- Очень изрядно, - сказал, ульгбаясь, Грибоедов.

еньковский съежслся и покосился на Грибоедова.

- Прочтите, крикнул он вдруг, - из «Гюлистана» стихи из рассказа семнадйать

- «Не подходи к двери эмира, визира и султана, не имея там тесных связей: швейцฺр, собака и дворник, когда почуют чужсого, - один хватает за ворот, другой за полу».

- Передайте по-русски лучше, - сипел, надорвавшись, Сеньковский.

Ученик молчал.

- По-русски это передано в прекрасных стихах, ставиих уже ныне пословицей, - сказал Сеньковский важно:

Мне завещзал отец::

Во-первых, угождать всем людям без изьятья-

Слуге, который чистит платье,

Швейцару, дворнику, для избежанья зла,

Собаке дворника, чтоб ласкова была.

И профессор сжался в ком с отчаянным видом. Грибоедов насупился и посмотрел на него холодно (Тынянов1988. 68-69).

В интересующем нас аспекте привлекают внимание следующие моменты: во-первых, дважды почти подряд повторенное деепричастие «улыбаясь». Как известно, А. С. Грибоедов не был ни улыбчивым, ни особенно приветливым. Деепричастие отображает побочное, сопровождающее действие, но оно всетаки было, и вызвало эту улыбку, несомненно, любимое произведение - 
«Гюлистан». Во-вторых, скрытая пикировка Сеньковского и Грибоедова: профессор, с одной стороны, похвалил стихи из известной комедии А. С. Грибоедова «Горе от ума», но, с другой стороны, указал на явную связь с текстом Саади, что очень не понравилось А. С. Грибоедову. В-третьих, прекрасное знание экзаменующимся персидской поэзии.

Отметим, что в тот период с произведениями персидских поэтов были знакомы интеллигентные люди, так, Ю. Н. Тынянов описывает библиотеку в Тифлисском доме: «А в большой комнате была еще библиотека, и здесь в шкафах были Саади и Гафиз, Чахрухадзе, Гете и новые английские журналы» (Там же. 170).

Для самого А. С. Грибоедова поэзия Саади значила очень много. Так, эпиграфом к 6-й главе являются стихи:

$$
\begin{aligned}
& \text { Ежеминутно уходит из жизни } \\
& \text { по одному дыханию. } \\
& \text { И когда обратим внимание, } \\
& \text { их осталось уже немного }
\end{aligned}
$$

\begin{tabular}{|c|c|}
\hline $\begin{array}{c}\text { Хар дам аз омр миравад нафаси Чун } \\
\text { негах миконам наманд баси. } \\
\text { (Саади, Гюлистан, Предисловие) }\end{array}$ & هردم ازعمر مى رود نفسى نهى منم نمانده بسى \\
\hline
\end{tabular}

А. С. Грибоедов знал Саади в подлиннике: «И он закрыл глаза и стал медленно читать по памяти стихи Саади, утешавшие его не мыслями, но звуками:

Обратим внимание на звукозапись - явление, о котором стали писать и которое стали изучать только в середине $\mathrm{XX}$ века, его связывают с импрессионизмом. 


\section{«Ежеминутно уходит из жизни по одному дыханию. И когда}

обратим внимание, их осталось уже немного».

Сашка лег спать

Халдам аз домр

Счеты сводились» (Тынянов 1988. 58).

Несмотря на то, что текст художественный, образ и судьба поэтадипломата А. С. Грибоедова представлены в нем поразительно точно, на что мы уже обращали внимание (Иванова 2018).

Следовательно, в XIX и XX веках специалисты и образованные люди были знакомы с персидской поэзией. Обратимся к конкретным ее представителям.

Наиболее цитируемым автором в нашем материале является Саади. Мы уже упоминали его творчество в связи с А. С. Грибоедовым. Модель описания в данном и последующих случаях такая: биографические данные, общая характеристика творчества, видение произведений русскими поэтами.

А. Н. Болдырев приводит следующие данные: Саади (псевдоним, настоящее имя - Муслихаддин Абу Мухаммед Абдаллах ибн Мушрифаддин; между 1203-1210, Шираз. - 9.XII.1292, Там же.) - персидский писатель и мыслитель (Болдырев 1971. Т. 6, 578).

В 30-х годах Саади посетил Мекку, более 20 лет странствовал в обличии дервиша по всему мусульманскому миру (от Индии и Кашгара до Йемена и Северной Африки). В Дамаске он написал поэму «Бустан» (авторское название «Саади - наме», 1257 г.). Второй шедевр, «Гулистан», написан в 1258 г. Саади вел полуотшельническую жизнь духовного наставника, «старца», в скромном подворье на окраине Шираза, где и был похоронен (Там же.).

Большинство произведений Саади, на которые ссылаются или которые упоминают русские авторы, носят назидательный проповеднический характер, что обусловлено жизнью и творчеством поэта. А.Н. Болдырев подчеркивает: 
Основу литературных проповедей Саади (а он считал себя прежде всего проповедником) составили светлые идеи человечности, гуманизма («адамийят», по его выражению). Он поведали их людям в музыкальных и ясных коротких песнях - газелях, впервые раскрывших целый мир простых человеческих радостей и печалей, а также в острых, метких, смелых и смешных притчах-рассказах «Гулистана» и отчасти «Бустана», из жизни и быта купца, бедняка, царя, раба, воина, мудреца, поистине из жизни народной. Огромной была и слава Саади, и влияние его на последующее развитие литературы (Там же.).

Над могилой поэта в 1952 г. был воздвигнут мавзолей. Это большая территория с деревьями, фонтанами, над которой льются стихи Саади. Обстановка умиротворенная. Все улыбаются, очень много детей - именно так надо пропагандировать поэзию вообще и творчество выдающегося поэта. Мы, восхищенные и удивленные, покидали мавзолей в 9 вечера, а в кассу стояла длинная, почти на целый квартал, очередь, несмотря на поздний час, люди пришли целыми семьями, вместе с маленькими детьми. Несомненно, Саади останется с ними на всю жизнь.

Обратимся к русским поэтам XIX-XX веков. Саади называли певцом Ирана (Н. С. Гумилев); традиционно сравнивали с соловьем (Н. С. Гумилев, П. Г. Ободовский, А. Н. Дельвиг), жаворонком (Д. Б. Кедрин), оценивали его как блистательного (Д. Б. Кедрин), сладостного (П. Г. Ободовский), подчеркивали его мудрость (Г. А. Санников), доброту (Г.А. Санников), но видели его почему-то только старым, седым (Г.А. Санников). Саади «ожерелья Аллы алмаз» (Н. С. Тихонов), воплощение нежности («Нежность, как песни Саади» — Есенин) (Есенин 1962. 118).

Более важным, на наш взгляд, является непосредственное обращение к творчеству Саади. Оно осуществлялось в четырех формах: перевод, пересказ, цитирование, подражание. 
Интересно, что А. С. Пушкин не в идентичных формах дважды цитировал одно и то же выражение: «Иных уж нет, а те далече, как Сади некогда сказал» («Евгений Онегин», глава VIII, строфа LI), «Многие так же, как и я, посещали сей фонтан; но иных уже нет, другие странствуют далече»; Сади (эпиграф к поэме «Бахчисарайский фонтан») (с. 123, 126).

Термин «перевод» практически не встречается, однако к данной рубрике мы относим стихи, обозначенные «Из Саади»: «Обращение к душе» Д. П. Ознобишина (с. 114-115), «Песню дервиша» Л. Н. Трефолева (с. 162), «На кусок янтаря» А.С. Хомякова (с. 170-171), «Шириазские розы» (Подражение «Гюлистану» Саади) К. А. Липскерова (с. 90-91).

В качестве образца приведем «Из Муслихаддина Саади» М. Л. Михайлова (1858г.).

Капля дождевая пала с тучи в море,

Где буграми волны ходят на просторе.

«Что же я-то в этой страшной бездне значу?-

Капля горевала, - здесь и жизнь утрачу!»

Но от темной доли в лоне вод суровом

Раковина каплю осенила кровом...

Сберегла от смерти, от беды и страха,

И теперь та капля - лучший перл у шаха (с. 99)

В некоторых случаях перевод, ссылка не обозначены, но назидательный смысл, стиль указывают на первоисточник: «Персидский романс П. Г. Ободовского (1825г.), «Закон» И. А. Бунина (1907г.).

«Закон» И. А. Бунина:

Во имя Бога, вечно Всеблагого!

Он, давший для писания тростник, 
Сказал: блюди написанное слово

И делай то, что обещяал язык.

Приняв закон, прими его вериги.

Иль оттолкни - иль всей душою чти:

Не будь ослом, который носит книги

Лишь потому, что их велят нести (Сирия, весна 1907г.) (с. 37)

Как «Подражание Саади» обозначили свои стихи «Вожатый каравана» С. И. Липкин (с. 80-81), «Шириазские розы» К. А. Липскеров (с. 90-91), Д. П. Ознобишин (с. 111, 113, 114-115), А. А. Фет (с. 167-168), А. А. Якубович (c. 186-187). Приведем примеры.

А. А. Фет:
«Обремененный славой мира,
Сравняйся с смоквою полей;
Она тем ниже гнется долу,
Чем смокв обильнее на ней (1844г.) (с. 168).

Таким образом, русские поэты на протяжении двухсот лет стремились сохранить назидательный дух поэзии Саади, его стиль, что, несомненно, способствовало более тесному знакомству образованного читателя с лучшими произведениями персидской поэзии.

Подчеркнем, что русских поэтов привлекало не только глубокое содержание, но и изысканная форма стихов Саади, не случайно И. Северянин неоднократно повторяет «изыски Саади».

Контекст показывает, что И. В. Северянин писал именно об изысканности, утонченности и оригинальности поэзии Саади:

Tыз знаешь, как внутренне рифмы звучат в персидской газэлле? В нечётких стихах, ты заметил, звук бел - в изыске Саади. Тебя не пугал 


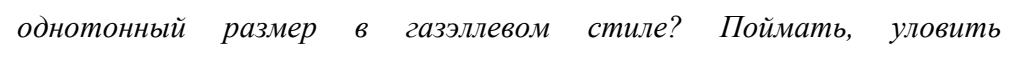

Еще одна частность: все русские авторы пишут о газелях. Как свидетельствует предпоследняя строка приводимого стихотворения, во избежание омонимии И.В. Северянин употребляет несколько иную номинацию - газэллы.

Последний момент, на который хотим обратить внимание, - звучание стиха, благозвучие. Мы уже упоминали о том, как успокаивающе звучали стихи Саади для А. С. Грибоедова в романе Ю. Н. Тынянова. У С. А. Есенина находим прямое звукоподражание:

Шёпот ли, шорох иль шелест-

Нежность, как песни Саади (Есенин 1962. 18) (с. 65).

В рассматриваемом сборнике стихи И. Л. Сельвинского построены на макаронической речи с дословным цитированием Саади. Но если обычно данный прием используется с целью создания комического эффекта, русский поэт стремится приблизиться к первоисточнику - поэзии Саади. Стихотворение начинается назиданием:

О роднике спроси того, кто знал пустыни желтый ад,

A тыл что знаешь о воде, когда перед тобой Евфрат?

Далее - традиционная изысканная любовная лирика.

О яр моя, сахибджамал! Красавииа моя, о яр!

Омиде ман, омиде ман, надежды, чаянья мои!

Хоть мы с тобой разлучень, но наших душ не разлучат. 
Авах! Газели Саади не тронут сердияа твоего...

Но если птииам их спою - от боли гнезда завопят! (с. 143)

Благодаря творчеству Саади русские поэты приобщились к образам и символам персидской поэзии, в какой-то мере перенеся их на родную почву.

Прежде всего это розы: «роза Гулистана» (М. Ю. Лермонтов), «Сладостная роза», «Шириазские розы» (К. А. Липскеров), «розы Шираза» (А. М. Чачиков).

В стихотворении «Шириазские розы» (Подражание «Гюлистану» Саади) К. А. Липскерова читаем:

$$
\begin{aligned}
& \text { «О друг... - И луч скользнул по старому челу. - } \\
& \text { Тебе и родине - народ в ней стал угрюмей, - } \\
& \text { Я книгу соберу. Я розами раздумий } \\
& \text { Наполню рукопись. Пускай мой сгорблен стан - } \\
& \text { Не будет осени в иветах многообразий». - } \\
& \text { «Я опростал полу» - «Получишь Гюлистан: } \\
& \text { Сады нетленнье рождаются в Ширазе». (с. 90-91) }
\end{aligned}
$$

В свою очередь отметим, что розы - это не только поэтический символ, но и живая распространенная реалия современного Ирана. Прилетев в Тегеран, мне пришлось какое-то время ждать коллег, чтобы вместе направиться в отель. Была глубокая ночь, но прибывали самолеты внутренних рейсов. Меня поразило, что буквально каждого пассажира, особенно пожилого, встречала группа людей, по всей вероятности семья, среди которых были маленькие дети. Все светились счастьем. Каждому прибывшему дарился дизайнерски оформленный букет из прекрасных роз. И еще одна деталь. Устроители конференции организовали нам незабываемую поездку с посещением ярких достопримечательностей страны, за которую я буду им всегда бесконечно 
благодарна. На протяжении всего трехдневного путешествия вдоль всех дорог продавали розы - белые, алые, чайные, на длинных стеблях. Естественно, продавцы и покупатели при общении с таким товаром благожелательно смотрели друг на друга.

Помимо розы, поэтическими символами являются караван (С. И. Липкин), соловей (П. Г. Ободовский, А. М. Чачиков).

Саади интересовал русских поэтов не только творчеством, но и человеческими качествами.

Возможно, глубина и мудрость стихотворений обусловили видение поэта как человека пожилого: «Старый, со «старым челом» (К. А. Липскеров), «седой», со «сгорбленным станом». Тем не менее, он «добрый» (Г. А. Санников), «блистательный» (Д. Б. Кедрин), «сладостный» (К. А. Липскеров).

Саади даже приписываются определенные поступки. Так, он выступил миротворцем в перебранке Омара и Магомета в стихотворении Д. Б. Кедрина «Кофейня»:

\footnotetext{
У поэтов есть такой обычай -

В круг садясь, оплевывать друг друга.
}

Стихотворение предваряет эпиграф:

Имеющий в кармане мускус

Не кричит об этом на улицах.

Запах мускуса говорит за него

Саadu

В процессе неприглядной ссоры зрители не были безучастны:

Старики кивали бородами,

Молодые говорили «Браво!» 
Эти две строки заканчивали каждый куплет с обвинениями. Характеристика Саади как поэта и человека глазами Д. Б. Кедрина:

\author{
Только некто пил свой кофе молча, \\ А потом сказал: «Аллаха ради! \\ Для чего пролито столько желчи?» \\ Это был блистательный Саади. \\ .. \\ Стал Саади золотой трубою, \\ И Саади слушала кофейня. \\ Как ароматические травы, \\ Слово пахло медом и плодами, \\ Юноши не говорили «Браво!» \\ Старијь не кивали бородами. \\ Он заворожил их песней птичьей,
}

Песней жаворонка в росах луга...(с. 71-72)

Об Омаре Хайяме и Хафизе, участниках конфликта, скажем позднее, однако очевидно, что для Д.Б. Кедрина творчество Саади благодаря естественности и близости к природе, неизмеримо выше.

Традиции восточной поэзии, заложенные Саади, сохранились на протяжении многих веков. Не случайно А. С. Пушкин называл поэтов Востока «сынами Саади»:
В прохладе сладостной фонтанов
И стен, обрызганных кругом,
Поэт, бывало, тешил ханов
Стихов гремучим жемчугом.
На нити праздного веселья 


\author{
Низал он хитрою рукой \\ Прозрачной лести ожерелья \\ И четки мудрости злотой. \\ Любили Крым сыны Саади (1828). (с. 120-121)
}

В порядке рассмотрения следующих поэтов попытаемся придерживаться наиболее объективного в нашем случае критерия - хронологии (даты рождения).

Фирдоуси. Абулькасим родился около 940 г. в местечке Табаран, умер в 1020 или 1030 г., персидский и таджикский поэт. В 976 г. он продолжил поэму «Шахнаме», начатую поэтом П. Дакики. Первую редакцию Фирдоуси завершил в 994 г., вторую - в 1010г., написав огромное по объему (около 55 тысяч бейтов) и глубокое по содержанию эпическое произведение мирового значения, отразившее национальный эпос персов и таджиков (Кр. л. энц. 1972. 995).

М.-Н. О. Османов характеризует поэзию Фирдоуси следующим образом: «Шахнаме» в определенной мере сохраняет черты героического эпоса с разработанными лексическими штампами, формулами, канонами поединков, перебранок героев. Вместе с тем сильна и традиция письменной литературы, которая складывается в философских диспутах, схоластических словопрениях, в многословных назиданиях. Историческая часть «Шахнаме» по форме приближается к версифицированной придворной хронике, стиль ее сжатый, за исключением тех эпизодов, которые представляют самостоятельные дастаны или новеллы. Фирдоуси не знает равных себе и в поэзии на фарси в батальных сценах и описании поединков. При этом он не избегал установившихся эпических норм, поэт выработал на основе эпоса средствами новоперсидского языка каноны описания массовых сражений и поединков (картины единоборства Рустама с Сухрабом, Рустама с Исфандияром и др.). 
Стиль Фирдоуси характеризуется чрезвычайным лаконизмом и определенной экспрессией, эпические штампы сосуществуют с сугубо индивидуальным отбором речевых средств. Лексика «Шахнаме» сравнительно с лексикой эпических текстов X века архаизирована, арабских заимствований в ней содержится мало (Османов 1972. 997).

Мы уже писали о звуковой организации поэзии Саади, о влиянии ее звучания на русских слушателей. Литературоведы отмечают, что одним из первых (или первый?) в персидской поэзии к звукописи прибегал Фирдоуси (Там же.).

В «Шахнаме» были заложены основы образной системы всей последующей персидской поэзии (Там же. 998).

Поэзия Фирдоуси известна в нашей стране. Первые переводы сделал В. А. Жуковский еще в XIX в., значительную часть эпопеи перевели в XX в. М. Лозинский, С. Липкин, В. Державин, Ц. Бану, М. Дьяконов.

В нашем материале к творчеству Фирдоуси обращался лишь С. А. Есенин. Для него Фирдоуси - олицетворение Персии:

Голубая родина Фирдуси,

Ты не можешь, памятью простыв,

Позабыть о ласковом урусе

И глазах, задумчиво простых,

Голубая родина Фирдуси.

Хороча тыл, Персия, я знаю,

Розы, как светильники, горят

И опять мне о далеком крае

Свежестью упругой говорят.

Хороша ты, Персия, я знаю (Есенин 1962. 24).

В стихотворении присутствует традиционный персидский поэтический символ - розы, о котором мы писали выше. Интересна и непонятна цветовая 
характеристика Персии - голубая. С. А. Есенин в Персии не бывал, его впечатления основывались на рассказах В.И. Болдовкина и переводах (Коваленко 1962. 229).

Данный эпитет не распространен в персидской поэзии, природа Ирана тоже его не активизирует, разве что удивительные изразцы, но они не могут быть воплощением всей страны. По всей вероятности, в данном случае проявились индивидуальные пристрастия автора: для С. А. Есенина голубой цвет, как правило, несет положительные коннотации.

Омар Хайям - Гиясаддин Абу-ль-Фахт ибн Ибрахим (родился около 1048 в. г. Нишапур) - персидский и таджикский поэт, математик и философ. Автор многочисленных математических и философских работ, а также получивших всемирную известность четверостиший (рубаи). По поручению сельджукского султана провел реформу календаря, но его очень точный календарь не был внедрен (Кр. лит. энц. 1968. 433).

М.-Н. О. Османов пишет о его творчестве: Омар Хайям пользуется несколькими основными мотивами, вокруг которых он нанизывает свои «вольнодумные» мысли: гончар, гончарная мастерская и кувшины символизируют творца, мир и индивида; трава, выросшая из земли, в которую превратился человеческих прах, подтверждает мысль поэта о вечном круговороте жизни и материи. Немалое место в его стихах занимает культ вина и гуляки (Османов 1968. 434).

Несмотря на широкую и многогранную деятельность О. Хайяма, для С. А. Есенина он прежде всего поэт:

Свет вечерний шафранного края,

Тихо розы бегут по полям.

Спой мне песню, моя дорогая,

Ту, которую пел Хаям. 
$\cdots$

Я спою тебе сам, дорогая,

То, что сроду не пел Хаям (Есенин 1962. 16-17).

В стихотворении С. А. Есенина возвращается к розе как символу поэзии, он же повторяется в последнем стихотворении цикла «Персидские мотивы», начинающемся непонятным для нас эпитетом «Голубая да веселая страна». С. Коваленко в примечании отмечает: «Беловой автограф, хранящийся у П. И. Чачина, имеет заглавие «Подражание Омару Хаяму» и дату - 8. IV-25, Баку» (Коваленко 1962. 238).

Данное указание, а также стиль стихотворения, традиционные повторяющиеся символы персидской поэзии («Слышишь, розу кличет соловей?») позволяют связать данное стихотворение с Омаром Хайямом.

В упоминавшемся уже стихотворении Д.Б. Кедрина «Кофейня» О. Хайям непонятно, на каком основании, предстает как скандалист. Их с Хафизом перебранка выглядит так:

Магомет, в Омара пальием тыча,

Лил ушатом на беднягу ругань.

Он в сердиах порвал на нем сорочку

И визжал в лиць, от злобы пьяный:

«Ты украл пятнадцатую строчку,

Низкий вор, из моего «Дивана»!

За твоими подлыми следами

Кто пойдет из думающих здраво?»

$\cdots$

А Омар плевал в него с порога

И шипел: «Презренная бездарность!

Да минет тебя любовь пророка 


\author{
Или падишаха благодарность! \\ Ты бесплоден! Ты молчишь годами! \\ Быть певиом ты не имеешь права!»
}

О том, что противником О. Хайяма является Хафиз, свидетельствует «Диван» - главное произведение последнего. Автор называет О. Хайяма «беднягой», что может свидетельствует о его сочувствии, но в целом история неприглядная. Возможно, она понадобилась Д. Б. Кедрину, чтобы противопоставить их Саади:

$$
\begin{aligned}
& \text { Иминуло время. Их обоих } \\
& \text { Завалил холодный снег забвенья. } \\
& \text { Стал Саади золотой трубою. }
\end{aligned}
$$

К счастью, все три поэта известны и почитаемы и в Персии, и в славянском мире.

Хафиз Шамседдин Мохаммед, родился около 1325 г. в Ширазе, в 1389 или 1390 г. Там же умер. Происходя из незнатной и небогатой семьи ширазских горожан, Хафиз, однако, получил полное богословское образование. Прекрасная память позволила ему овладеть сложным искусством рецитации Корана, который он знал наизусть наряду с огромным количеством арабских хадисов: отсюда принятое в таких случаях наименование «хафиз» (т.е. «хранящий в памяти») (Кр. л. энц. 236).

Главное произведение Хафиза - «Диван», собранный после его смерти и распространившийся в большом количестве в Иране и за его пределами.

А. Н. Болдырев характеризует творчество Хафиза следующим образом: «В лирике Хафиза преобладают традиционные темы вина и любви, мистические озарения, славословия, жалобы на бренность и непознаваемость мира. Однако если в традиционной поэзии такие темы, как правило, решаются отвлеченно и безлично, то лирический герой Хафиза - полнокровный, живой человек, 
одержимый кипением противоречивых страстей: он то аскет, мистик и духовидец, то скептик, вольнодумец и мечтатель, возвещающий человечеству наступление светлого земного царства, то забулдыга и дебошир, нарушитель спокойствия, до грубости резко обличающий духовенство и власть имущих. И если в центре поэзии Хафиза стоит тема неистового эгоцентрического наслаждения, в этом следует видеть стремление поэта уйти от современной жестокой действительности.

Хафиз широко использует в своих газелях образы и термины традиционной суфийской поэзии, которые обычно допускают возможность двоякого толкования - прямого реалистического и переносного, символического.

Творчество Хафиза в целом представляет собой высшее достижение всей средневековой персоязычной лирической поэзии. Его стихи переведены на все европейские и многие азиатские языки. В современном Иране «Диван» Хафиза стоит на первом месте среди всех переизданий классического наследия» (Болдырев 1975. 237).

Рассмотрим, как обычно воспринимали Хафиза русские поэты.

А. А. Дельвиг трактует Хафиза и Саади как равноценных певцов Ирана соловьёв:

$$
\begin{aligned}
& \text { Близ вас поют певць Ирана, } \\
& \text { Гафиз и Сади - соловьи (А. Н. Карелиной, } 1827 \text { г.). }
\end{aligned}
$$

Так же представляет данных поэтов Г. А. Санников:

Полюбил я лирику Хафиза

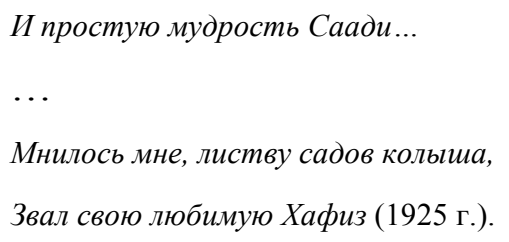


В «Кофейне» Д. Н. Кедрина представлен скорее не Хафиз, а его персонаж «забулдыга и дебошир», по словам А. Н. Болдырева.

Русских поэтов беспокоила судьба персидских поэтов и поэзии. В видении А. С. Пушкина восточная поэзия будет развиваться «сынами Саади», ему вторит Д. Б. Кедрин, хотя считает, что Омара Хайяма и Хафиза «Завалил холодный снег забвения», А. А. Суркова волнует наступление английской речи, которая может заглушить «бархатный говор Востока». В стихотворении «Шираз» (1946г.) он, в частности, пишет:

\author{
Знаменитые розы Шираза \\ Увядают, жарой спалены... \\ .. \\ В этом городе жили поэты \\ Саади, Кермани и Хафиз... \\ ... \\ Как среди этой прозы жестокой \\ Нежность речи певучей сберечь, \\ Если бархатный говор Востока \\ Заглушает английская речь. \\ Если нищий народ бессловесен, \\ А в богатых домах напоказ \\ Вместо старых, задумчивых песен \\ Ржет, скрежещет, мяукает джаз... \\ .. \\ Если нынешним Ксерксам и Кирам \\ Сшит в Нью-Йорке ливрейный наряд. \\ От недоброго, жадного глаза \\ Осыпаются роз лепестки,
}




\section{И к могилам поэтов Шираза}

Из пустынь подступают пески.

К счастью, опасения А. А. Суркова в Иране наших дней не оправдались. Богачи не прислуживают в американских ливреях в Нью-Йорке. Главное народ свято хранит память о своих поэтах, построив прекрасные гробницы, над которыми постоянно звучат их стихи. Дети с младых ногтей приобщаются к великой культуре предков, а народ хранит их традиции.

\section{Заключение}

Подводя итоги, отметим следующее.

1. Несмотря на то, что поэты не бывали в Персии, эта страна была им близка прежде всего благодаря произведениям персидских поэтов. Даже их имена произносили часто на свой лад: Так, Саади стал (возможно, благодаря А. С. Пушкину) Садѝ, Саа̀ди, Фирдоусѝ - Фирду̀си, Хайя̀м - Хая̀м.

Однако отношение к творчеству представителей средневековой персидской поэзии внимательное, бережное и трепетное. В нашем материале представлены Саади, Фирдоуси, Омар Хайям, Хафиз. Русские поэты обращаются к традиционным символам поэзии - розам, соловьям.

2. В лингвоимагологическом исследовании всегда подчёркивается, что оценка характеризует не столько само явление, сколько оценивающего. В нашем случае русские поэты предстают образованными, эрудированными и очень доброжелательными людьми, обладающими несомненным поэтическим дарованием. Такова традиция, существующая на протяжении столетий (мы рассмотрели XIX - XX века). Погружаясь в мир далёкой загадочной страны, поэты создавали шедевры русской литературы. 


\section{Литература}

1- Болдырев А.Н. (1971). Саади. Краткая литературная энциклопедия, т.6 // М.: «Советская энциклопедия». С.576-580.

2- Болдырев А.Н. (1975). Хафиз. Краткая литературная энциклопедия, т.8 // М.: «Советская энциклопедия». С.236-237.

3- Брагинский И.С. (1968). Персидская литература. Краткая литературная энциклопедия, т.5 // М.: «Советская энциклопедия». С.678-695.

4- Есенин С.А. (1962). Собрание сочинений в 5 томах. Т.3. Стихотворения и поэмы (1924-1925) // М.: ГИХЛ. - 279с.

5- Иванова Л.П. (2018). Отображение персидских реалий начала XIX в. в русском художественном тексте XX в. (на материале романа Ю.Н. Тынянова «Смерть Вазир - Мухтара»). - Language Atr. 3 (4) pp 93-104. Shiraz. Iran

6- Коваленко С. (1962). Примечания. Сергей Есенин. Собрание сочинений в 5 т., т.3. Стихотворения и поэмы (1924-1925) // ГИХЛ, М., с.215-275.

7- Османов М.-Н. О. (1968). Омар Хайям. Краткая литературная энциклопедия, т.5 // М.: «Советская энциклопедия». С.434-435.

8- Османов М.-Н. О. (1972). Фирдоуси. Краткая литературная энциклопедия, т.7 // М.: «Советская энциклопедия». С.995-998.

9- Тынянов Ю.Н. (1988). Смерть Вазир - Мухтара: Роман. Послесловие, примечания, Б.О. Костелянца // К.: «Дніпро». - 464 с.

10- Яхьяпур М., Карими-Матаххар Дж. (2017). Саади и русские поэтьь, Тегеран: Тегеранский университет.

\section{Bibliography}

1- Boldyrev A.N. (1971). Saadi. Kratkaja literaturnaja jenciklopedija, t.6 // M.: «Sovetskaja jenciklopedija». S.576-580.

2- Boldyrev A.N. (1975). Hafiz. Kratkaja literaturnaja jenciklopedija, t.8 // M.: «Sovetskaja jenciklopedija». S.236-237.

3- Braginskij I.S. (1968). Persidskaja literatura. Kratkaja literaturnaja jenciklopedija, t.5 // M.: «Sovetskaja jenciklopedija». S.678-695.

4- Esenin S.A. (1962). Sobranie sochinenij v 5 tomah. T.3. Stihotvorenija i pojemy (1924-1925) // M.: GIHL. - 279s. 
5- Ivanova L.P. (2018). Otobrazhenie persidskih realij nachala HIH v. v russkom hudozhestvennom tekste HH v. (na materiale romana Ju.N. Tynjanova «Smert' Vazir - Muhtara»). - Language Atr. 3 (4) pp 93-104. Shiraz. Iran

6- Kovalenko S. (1962). Primechanija. Sergej Esenin. Sobranie sochinenij v 5 t., t.3. Stihotvorenija i pojemy (1924-1925) // GIHL, M., s.215-275.

7- Osmanov M.-N. O. (1968). Omar Hajjam. Kratkaja literaturnaja jenciklopedija, t.5 // M.: «Sovetskaja jenciklopedija». S.434-435.

8- Osmanov M.-N. O. (1972). Firdousi. Kratkaja literaturnaja jenciklopedija, t.7 // M.: «Sovetskaja jenciklopedija». S.995-998.

9- Tynjanov Ju.N. (1988). Smert'Vazir-Muhtara: Roman. Posleslovie, primechanija, B.O. Kosteljanca // K.: «Dnipro». $-464 \mathrm{~s}$.

10- Jah'japur M., Karimi-Matahhar Dzh. (2017). Saadi i russkie pojety, Tegeran: Tegeranskij universitet. [In Russian \& Persian]

\section{HOW TO CITE THIS ARTICLE}

Ivanova L. P. (2021). Iranian Poets and Poetry in the Vision of

Russian Poets (Linguoimagological Aspect). Issledovatel'skiy

Zhurnal Russkogo Yazyka I Literatury, 9(2), 27-51.

DOI: $10.52547 /$ iarll.18.27

URL: https://journaliarll.ir/index.php/iarll/article/view/212

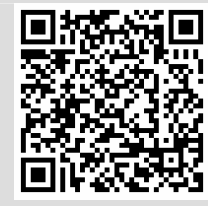




\section{شاعران و شعر ايرانى از دريجٌه نحاه شاعران روسى (رويكرد تصويرشناختى -زبانى)}

$$
\begin{aligned}
& \text { ليودميلا بتروونا ايوانووا' }
\end{aligned}
$$

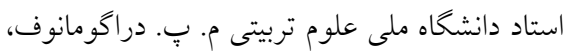

$$
\begin{aligned}
& \text { كيف، اوكراين. }
\end{aligned}
$$

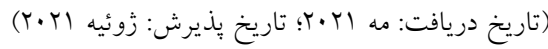

جكيده

در مقاله بر اساس آثار شاعران روس كه دربـارة ايــران و ايـران باسـتان اشـعارى سـرودند

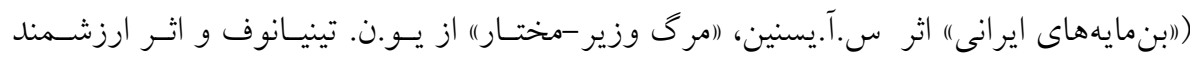

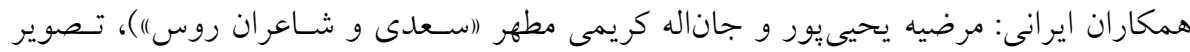

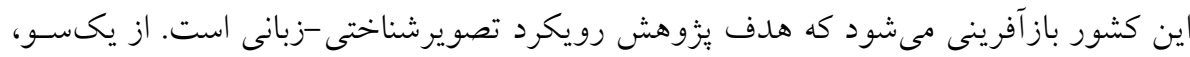

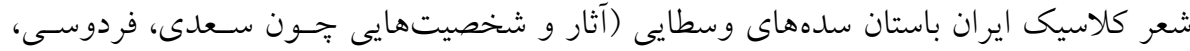

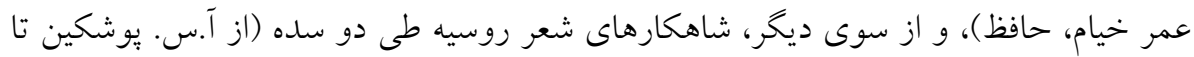

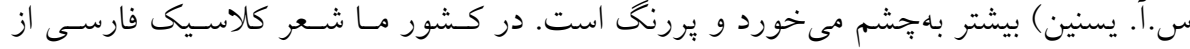

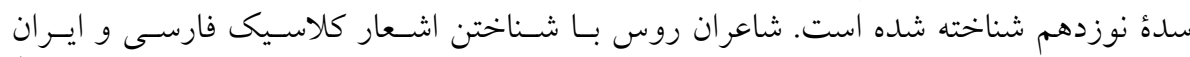

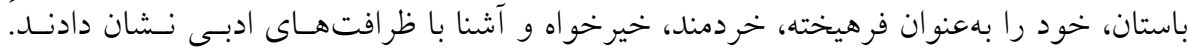

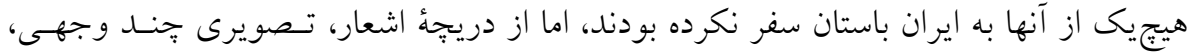
زيبا و بر رمزورازى از اين كشور را ارائه مى كنند.

وازگكان كليدى: تصويرشناختى - زبانى، شعر فارسى و شاعران ايرانى، سعدى، فردوسى، عمـر

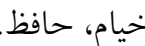

